\title{
WI-FI BASED HOME AUTOMATION SYSTEM USING AURDINO
}

\author{
Snehal .R . Waghmare ${ }^{1}$, Komal .D. Wategoankar ${ }^{2}$, Trishala .B. Patil ${ }^{3}$, Amruta .M. Shinde ${ }^{4}$ \\ ${ }^{1}$ B.E, Student, Electronics \& Telecommunication, ADCET, Ashta, Maharashtra, India \\ ${ }^{2}$ B.E. Student, Electronics \& Telecommunication, ADCET, Ashta, Maharashtra, India \\ ${ }^{3}$ B.E. Student, Electronics \& Telecommunication, ADCET, Ashta, Maharashtra, India \\ ${ }^{4}$ B.E. Student, Electronics \& Telecommunication, ADCET, Ashta, Maharashtra, India
}

\begin{abstract}
This paper represents the idea of home automation system using wireless technology. Wireless technology widely used for communication purpose these advanced technology changes every person constantly. In today's world automation plays very important role and in these project home appliances controlled through the human interaction with the Wi-Fi technology. The home appliances are controlled manually through PC or mobile phone in same local area network. The home is become fully automated which depends upon sensor reading. Another mode is used in this project is security mode. Now a day's security of home is need of everyone which alerts the user if anyone enters in the area of the main entrance or the password entered is incorrect then these systems becomes active.
\end{abstract}

Keywords: Arduino, WI-FI technology, LCD Display, Low Cost, Home Automation.

\section{INTRODUCTION}

Wireless technologies are more popular around the world which improves our lives. Today we are living in the $21 \mathrm{st}$ century where home automation plays a vital role which controls the appliances like fan, door, light etc.

Now days, home automation is one of the major applications of WI-FI and other wireless technology there are a number of ways access control through PC or mobile which provides security and the emergency activated the system. It takes advantage of wireless communication between device and authentification to perform the identification. In this project, we propose a home automation system that can control home appliances from a PC or mobile phone using Wi-Fi and in this, we present a low cost secure, flexible home automation system.

Propose home automation system to modern life is the systems which focus on providing a low cost with highly reliability and security. This system uses a device like mobile phone commonly found in the normal household can be connected to a local network inside a home with electronic equipment. The device or mobile is first logged on the server then there is an authentication confirmation is done. In this paper controlling of light and fan speed is the specialty of the paper as well as door lock system is the key linchpin of security. For that purpose, there is a password system no one can enter a home without a personal password. [1]

The buzzer is used in this project at door lock system if the password is incorrect then buzzer automatically on. Home automation is centralized control of light, fan speed, door, and other electronic appliances. It reduces the human's efforts and energy efficiency and it is a time- saving activity. This paper goal is smart city approach towards reduces the labor costs and improves the quality of life. The scope of this project not only restricted to home it can be expanded to many other areas. [2]

Home automation is nothing but automation of home or it is a household work, household activities. It provides the remote interface developing after huge efforts to home appliances via mobile phone, PC or wireless networks. In this project for the security system, we are targeting the android platform through these android device gives the command communicate with the Arduino controller to control household activity. The android has an operating system based on Linux. It contains different function when the application starts by the user it first authenticates if user authorized it will navigate to the main screen. The main screen has a list of different function the user can choose anyone of them.[3]

Currently, home automation systems are used in homes to control appliances and in industries for lightning and security purpose etc. but deaf people, elderly people, disabled people faces problem-related to controlling home appliances. To overcome these problems, designed "Wi-Fi Based Home Automation system using Arduino" as shown in figure 1. This system can be used in home, offices, industries etc. [4]

As the country is making its development through digitalization, our home automation system is one step towards making the smart city.

This paper approach towards the controlling of home appliances by implementing the appliances and various systems are difficult to design and maintain compare to current system is very customizable. 


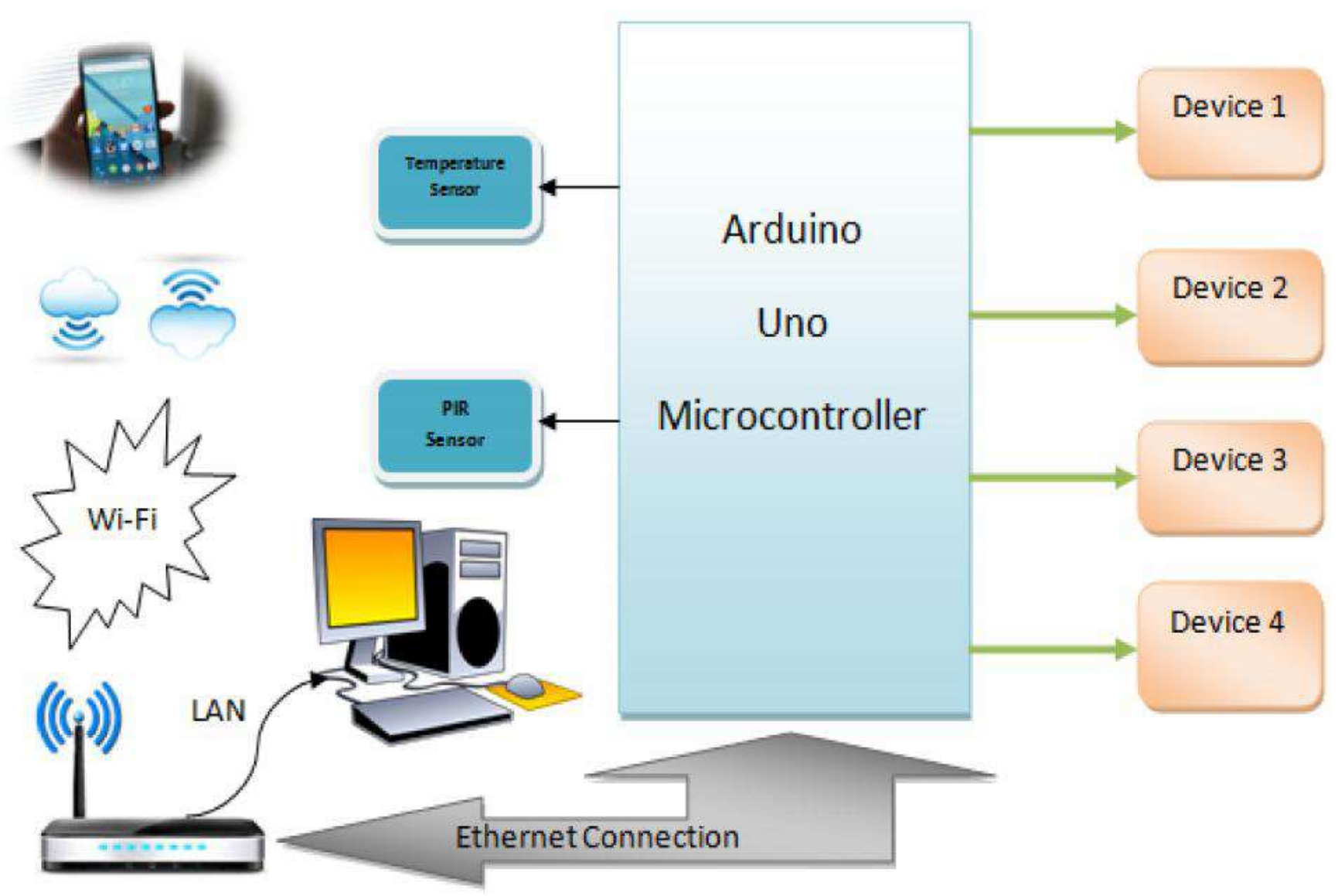

Fig.1:-Conceptual diagram of home automation system (HAS)

\section{PROBLEM DEFINATION}

People who are disabled, handicapped or deaf can't operate the appliances in the home or they can't reach those things. So home automation is not done by the efficient way. It becomes difficult and unsecured. To minimize these abovementioned problems a simple home automation system designed in which the modem of Wi-Fi interfaced with door lock device controlled.

\section{METHODOLOGY}

Fig. 2 shows hardware loop diagram. Arduino is the main control unit. All the applications will be controlled by Arduino. Various sensors like temperature, IR sensors are controlled by Arduino. In this system $\backslash$ LCD is used to display the entered password.

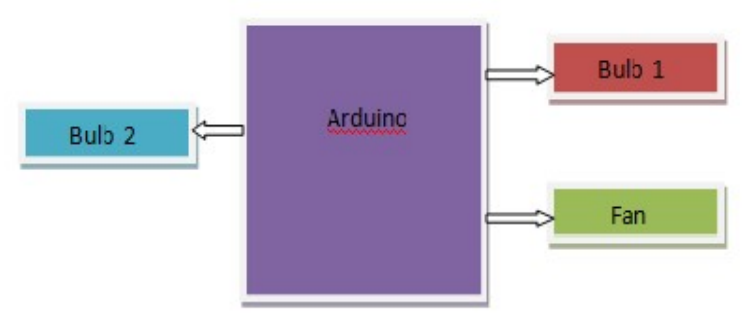

Fig 2. Device controlled
Fig3. Describe the door lock system. In this, we enter the password using mobile phone which is display on LCD. And open the door if a password is correct and vice-versa.

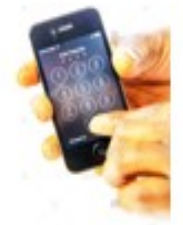

Enter password

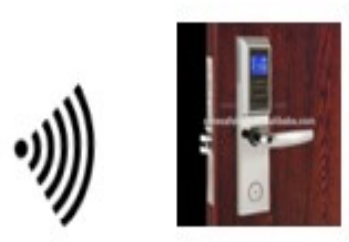

Door lock

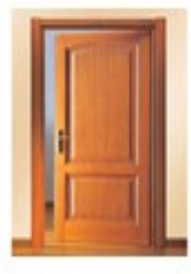

Open Door
Fig 3. Door-lock System

Figure4. Shows the block diagram of the home automation system using wireless technology. The main control unit of the system is Arduino Uno microcontroller; it controls the overall units as well as the flow of the system. Various parameters like sensor unit, LCD display, power supply unit and load control unit are present. Sensor unit consists of the motion sensor, temperature sensor and IR sensor in which motion sensor detect the unauthorized movements.LCD display is used in this project used at door lock system for displaying the password. Also, there is a power supply unit is interfaced with the whole circuit. In terms of lightning and security bulb, door and fan an interface to Arduino. Load control unit consists of Relay. The relay acts as a switch. 
At the door lock system if type password is wrong then buzzer is active. The Wi-Fi modem is connected through local area network to mobile device or PC inside the home by using this connection via mobile app electric appliances are controlled or operated.

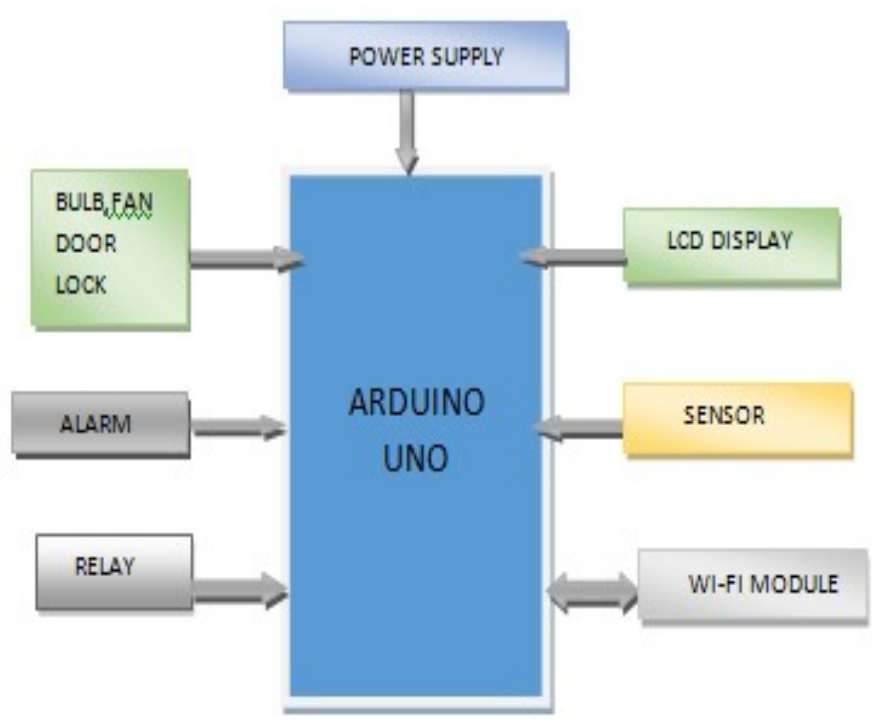

Fig. 4-Block diagram of HAS

\section{APPLICATION}

- This technology is used in lightning control it is useful for saving energy by auto on/off in houses, At night times in major city office buildings, Educational institute after 6 pm etc.

- In the door lock password based system it is the key technology of security.

- It is used to control the speed of the fan.

- The security system includes a motion sensor which detects the unauthorized movements detect by this system and alert the user.

\section{CONCLUSION}

As our proposed system assists for handicapped/old or aged people. This paper gives an idea about how to control the home appliances. This project is based on the Wi-Fi and Arduino based which is easy to design and improves the standard of living. The security system is effective as well as safe.

This is the simple prototype of the home automation system in future this system may expand in many areas.

\section{ACKNOWLEDGEMENT}

We would like to express our special thanks to Prof.S.S.tamboli for her special guidance and encouragement at Annasaheb Dange College of Engineering and Technology, Ashta. 416301; Maharashtra, India. His active cooperation in this project development is very helpful for us and also helped me for writing this review paper.

\section{REFERENCES}

[1]. P Pavan Kumar, G Tirumala Vasu "Home Automation System and Security System using Arduino". International Journal of Emerging Trends in Engineering Research. Vol. 3, No.6, Pages: 190-194(2015).

[2]. Mahesh N. Jivani "GSM Based Home Automation System Using App-Invertor for Android Mobile Phone" International Journal of Advanced Electrical, Electronics And Instrumentation Engineering. Vol. 3, Issue 9, September 2014.

[3]. R Piyare and M.Tazil. 2011."Bluetooth Based Home Automation System Using Cell Phone".IEEE $15^{\text {th }}$ International Symposium on Consumer Electronics
[4].
Arduino
Development
Environment, http://arduino.cc/en/guide/Environment

\section{BIOGRAPHIES}

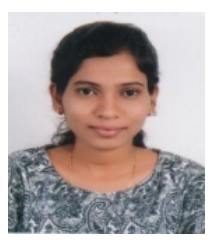

Miss.Snehal Ramesh Waghmare, B.E ETC student of Annasaheb Dange College of Engineering and Technology, Ashta.

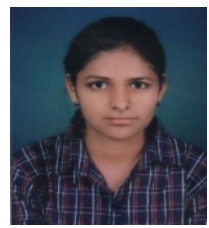

Miss.Komal Dattatray Wategoankar, B.E ETC student of Annasaheb Dange College of Engineering and Technology, Ashta.

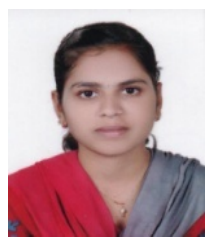

Miss.Trishala Balaso Patil, B.E ETC student of Annasaheb Dange College of Engineering and Technology, Ashta.

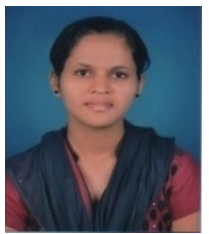

Miss.Amruta Mansing Shinde, B.E ETC student of Annasaheb Dange College of Engineering and Technology, Ashta. 